Kaygı, 20(I)/2021: 325-345. Araştırma Makalesi | Research Article

Makale Geliş | Received: 26.08.2020

Makale Kabul | Accepted: 06.03.2021

Yayın Tarihi | Publication Date: 15.03.2021

DOI: 10.20981/kaygi.893234

Esma KAYAR

Arş. Gör. | Res. Assist. İstanbul Medeniyet Üniversitesi, Edebiyat Fakültesi, Felsefe Bölümü, İstanbul, TR Istanbul Medeniyet University, Faculty of Letters, Department of Philosophy, İstanbul, TR

ORCID: 0000-0001-8429-4402

esmakayar@gmail.com

\title{
Megaralı Philon'da Koşullu Önerme Anlayışı ve Modern Mantıkta Maddi İçerme Kavramının Oluşumu
}

$\ddot{O} \mathbf{z}$

"Eğer A ise, o halde B" olarak sembolleştirilebilecek koşullu önermelerin doğruluk değerinden ilk bahseden filozoflardan biri Megaralı Philon'dur (ö. M.Ö. 3. yy). Philon koşullu bir önermenin yanlış değeri almaması için asgari şartı belirlemiştir. Bu şarta göre ön-bileşeni doğru ard-bileşeni yanlış değer almayan bir koşullu önerme doğru kabul edilir. Philon'un koşullu önermelerinin doğruluk değeri almasında onun modalite anlayışının da etkisi vardır. Philon'un doğruluk değeri alan önerme örneklerinin olgusal veriler üzerinden değerlendirildiği görülmektedir. Stoacılar sonrasında önemi azalmış görünen koşullu önermelerin doğruluk değeri tartışması modern dönemde Frege'nin koşulluluk eklemini sembolleştirmesi ile yeniden canlanmıştır. Frege koşullu önermelerde bahsedilen "Eğer ... ise, o halde ..." yapısının fiziksel nedensellikten geniş olduğunu göstermiştir. Peirce koşullu önermelerle ilgili modern sembolleştirmenin gelişimini etkilemiş ve mantıksal olanak olarak koşullu önerme yapısının açıklanmasına katkıda bulunmuştur. Russell ise formel içermeden ayırt ederek maddi içermeyi tanımlamıştır. Bu çerçevede "Eğer A ise, o halde B" koşullu önermesi Philoncu maddi içerme yoluyla "A içerir B" tabiri olarak anlaşılmıştır.

Anahtar Kelimeler: Koşullu Önermeler, Megaralı Philon, Modalite, Modern Mantık, Maddi İçerme.

\section{The Theory of Conditional Propositions in Philo of Megara and the Formation of Material Implication in Modern Logic}

\begin{abstract}
Philo of Megara (d. 3rd century BCE) is one of the first philosophers who assigned truth values to conditional propositions that can be symbolized as "If A, then B". He determined the minimum criterion for a conditional proposition not to bear a false truth value. According to this criterion, a conditional proposition that doesn't have a true antecedent and false consequent is regarded as a true conditional. Philon's conception of modal terms helps us to understand his theory of conditionals. We need factual data to be able to assess the truth values of Philoanian conditional propositions. The discussion about conditional propositions regarding their truth values lost its importance after Stoics until the modern era. Frege revitalizes the subject by introducing his notation of conditionals. He presents how the "If ..., then ..." form of the conditional proposition is different from physical causality. Peirce made a contribution to the notation of symbolic logic about conditionals and, explained conditional propoistions in the context of logical possibility. Russell defined material implication as distinguished from formal implication. Via the material implication, Philonian conditional proposition "If A, then B" is understood as "A implies B".
\end{abstract}

Keywords: Conditional Propositions, Philo of Megara, Modality, Modern Logic, Material Implication. 


\section{Giriş}

Koşullu önermeler iki cümle ya da cümle benzeri yapıdan oluşur. "Eğer A ise, o halde B”dir olarak sembolleştirebileceğimiz bir koşullu önermede A'lı cümle ön-bileşen B'li cümle ise ard-bileşen olarak nitelendirilir. Koşullu bir önermenin doğru ve yanlış değeri alması onun ön-bileşen ve ard-bileşeninin doğruluk ve yanlışlığına göre belirlenen bir durumdur (Kneale \& Kneale 1971: 130). Önermelere merkezi bir rol veren ve koşullu cümlelere doğruluk değeri atfeden ilk filozofların Megara okulundan (Diyalektik okul olarak da bilinmektedir) Philon ve Diodoros Kronos (ö. M.Ö. 284 civar1) olduğu kabul edilmektedir (Borghini 2016: 31). Cicero’ya (ö. M.Ö. 43) göre koşullu önermelerin ne zaman doğru olduğu klasik dönemdeki önemli tartışmalardan birisidir:

Eğer gündüz ise, o halde hava aydınlıktır” tarzında bağlanmış bir argümanın doğru mu yanlış mı olduğu nasıl yargılanacak, bununla ilgili nasıl da büyük bir münakaşa var; -Diodoros'un başka bir görüşü var, Philon'un bir başka (Cicero, Acad. Quaest. LCL 268: 652-653). ${ }^{1}$

Sextus Empiricus (ö. 210 civarı) "Bilginlere” Karşı eserinin "Mantıkçılara Karşı” başlıklı kitabında diyalektikçiler diye isimlendirdiği bazı filozofların mantıksal olarak koşullu bir önermenin ard-bileşeni, ön-bileşenini takip ettiğinde koşullunun sağlam olduğu iddiasında anlaştıklarını belirtmektedir. Ancak ona göre bu takip etmenin ne zaman ve nasıl olduğu konusunda ise anlaşmazlık bulunur. (Empiricus, Adversus Mathematicos, VIII, 113-17). ${ }^{2}$ Bu anlaşmazlığın başlangıcı Megara okulu filozoflarına götürülebilir olsa da tartışma Stoacı filozoflar ile daha ileri boyutlara taşınmış ancak daha sonraki uzun yüzyıllar boyunca koşullu önermelerin özellikleri tartışılsa da önermeler mantığı etkisini yitirmiştir. Modern mantıkla birlikte önermeler mantığı önem kazanmaya başlayınca koşullu önermeler ile ilgili tartışmalar da yeniden canlanmıştır. Megara okulu filozoflarının koşullu önermeler hakkındaki fikirleri Stoa

\footnotetext{
${ }^{1}$ İngilizcesi: Yonge 1872: 91 .

${ }^{2}$ İngilizcesi: Bett 2005: 114.
} 
mantığına olan ilgili ile birlikte artmış ancak bu okulun fillozoflarının görüşleri kendi başına son zamanlarda incelenmeye başlanmıştır.

$\mathrm{Bu}$ makalede öncelikle Stoa mantığından bağımsız olarak Philon'un klasik kaynaklardan aktarılan koşullu önerme anlayışı ele alınacak ve bu tarz önermelerin doğruluk değerleri modalite konusuna bağlanarak incelenecektir. Bu inceleme ile öncelikle tarihsel açıdan Aristoteles mantığı ile Stoa mantığı arasında bir geçiş dönemine denk gelen Megaralı Philon’un mantıkla ilgili görüşlerinin bağımsızca ele alınmasının bahsedilen iki mantık arasındaki ilişkilerle ilgili gelecekteki çalışmalara katkı yapması amaçlanmaktadır. Makalede daha sonra modern sembolik mantıkta doğruluk fonksiyonu üzerinden ele alınan "maddi içerme" tablosu Philon'daki koşullu önerme anlayışına denk düştüğü için maddi içerme kavramını ortaya çıkaran fillozoflar incelenecektir. Bu bağlamda Frege'nin koşullu önermeyi ve koşulluluk eklemini belirgin bir şekilde sembolik mantığa dahil edişine değinilecek, Peirce'nin koşullu önerme ve olanaklılık anlayışının koşullu önermelere yansıması işlendikten sonra ise Russell'in koşullu önerme tabirini "formel içerme"den ${ }^{4}$ ayırt ederek "maddi içerme"ye dönüştürmesi tartışılacaktır.

\section{Philon}

Megaralı Philon'un koşullu önerme anlayışıyla ilgili temel kaynak Sextus Empiricus'tur. Empiricus Pyrrhonculuğun Esasları eserinde Philon için doğru bir önbileşen ve yanlış bir ard-bileşene sahip olmayan bir koşullunun sağlam olduğunu söylemektedir. Gündüz ise ve konuşuyorsam "Eğer gündüz ise, konuşuyorum" önermesinde olduğu gibi. (Sextus Empiricus, PH, II 110-111)..$^{5}$ Yine o "Bilginlere" Karşı 'da bu durumu daha detaylıca ele almaktadır. Burada Philon için koşullu bir önermenin doğru ile başlayıp yanlışla bitmediği takdirde doğru olduğunu yazmaktadır. Eserin aktardığına göre Philon için koşullu bir önerme aşağıdaki ilk üç durumda doğru ve dördüncü durumda ise yanlıştır:

\footnotetext{
${ }^{3}$ İng. Material implication. Türkçede maddi gerektirme tabiri de kullanılmaktadır.

${ }^{4}$ İng. Formal implication.

${ }^{5}$ İngilizcesi: Bury 1976: 221.
} 
1- Doğru ile başlar doğru ile biterse: "Eğer gündüz ise, hava aydınlıktır" (D)

2- Yanlış ile başlayıp yanlış ile biterse: "Eğer dünya uçuyorsa, dünyanın kanatları vardir" (D)

3- Yanlış ile başlayıp doğru ile biterse: "Eğer dünya uçuyorsa, dünya vardır”(D)

4- Doğru ile başlayıp yanlış ile biterse: Gündüz vakti söylenmiş olan "Eğer gündüz ise, gecedir" (Y)

(Sextus Empiricus, Adversus Mathematicos VIII, 113-17). ${ }^{6}$

Empiricus'a göre Philon yine şu ilk üç cümleyle ilgili doğru dördüncü cümle ile ilgili ise yanlış doğruluk değeri vermiştir;

a. "Eğer gündüz ise, konuşuyorum" koşullu önermesi gündüz konuştuğumda doğrudur çünkü o doğru bir ifade olan "Gündüzdür" ile başlamış ve yine doğru olan "Konuşuyorum" ifadesi ile bitmiştir.

b. "Eğer gece ise, konuşuyorum" koşullu önermesi gündüz olduğunda ve konuşmadığımda doğrudur, çünkü yanlışla başlar ve yanlışla biter.

c. "Eğer gece ise, gündüzdür" koşullu önermesi gündüz ise "Gecedir" yanlış ifadesi ile başlayıp "Gündüzdür” doğru ifadesi ile bittiği için doğrudur.

d. "Eğer gündüz ise, konuşuyorum” koşullu önermesinin doğruluk değeri gündüz ise ve konuşmuyorsam yanlış olacaktır.

(Sextus Empiricus, Adversus Mathematicos VIII, 113-17) ${ }^{7}$

Susanne Bobzien, Philon'un koşullu önermelerinin doğruluk değerinin zaman ile değişebildiğini söylemektedir (Bobzien vd. 2008: 85). Ancak gece ve gündüzle ilgili örneklerin aksine "Eğer dünya uçuyorsa, dünya vardır” örneğindeki doğruluk değerinin zamana bağlı olduğunu söylemek kolay değildir. Dünyanın var olması bizim bilim algımıza göre bir zaman meselesi olarak görülebilirse de Philon'un çağdaşı filozofların dünyayı ezeli-ebedi bir varolan olarak düşündüklerini dikkate almak gerekir. Yine "Eğer gündüz ise, hava aydınlıktır" koşullu önermesi de Philon için zamandan bağımsız bir doğruluk değerine sahip görünür.

\footnotetext{
${ }^{6}$ İngilizcesi: Bett 2005: 114.

${ }^{7}$ İngilizcesi: Bett 2005: 114.
} 
Empiricus Pyrrhonculuğun Esasları eserinde Philon'un koşullu önerme anlayışını açıkladığı yerde koşullu önermelerle ilgili Philon dışındaki filozoflara ait üç farklı koşullu önerme anlayışından daha bahsetmiştir. Bunlardan ilki olan Diodoros Kronos'un koşullu önerme görüşüne göre Philon için doğru olan "Eğer gündüz ise, konuşuyorum" önermesi gündüzken konuşmayabileceğimiz için yanlıştır çünkü böyle bir durumda doğru bir ön-bileşeni yanlış bir ard-bileşen takip etmiş olacaktır. ${ }^{8}$ İkinci anlayışa göre yalnızca ard-bileşeninin karşıtı, ön-bileşeni ile "çelişen” önermeler doğru olacağı için Diodoros'un doğru kabul ettiği koşullu önermeler bu anlayışta yanlış olabilir. Üçüncü anlayış ise ard-bileşenin ön-bileşende içerilebilmesi koşulunu getirir ve bu da ikinci anlayışın doğru kabul ettiği koşullu önermelerin yanlış olabilmesi sonucunu doğrurur. Örneğin "Eğer gündüz ise, gündüzdür” önermesi ikinci anlayış açısından doğru iken üçüncü anlayışa göre güzdüzün gündüzde içerilmesi makul görünmediğinden yanlış olacaktır. ${ }^{9}$ Yorumcular Empiricus'un ilgili paragrafa Philon'un tanımıyla başlamasını diğer tanımlarla kıyaslanınca içlerinde en zayıf olanın Philon'un koşullu önerme anlayışı olmasının bir işareti olarak düşünmüştür (Mates 1961: 45; Bobzien vd. 2008: 84; O’Toole \& Jennings 2004: 479-480). Empiricus gerçekten de bir sonraki anlayışın bir öncekinin koşullu önermelerinin doğruluk değerini sınırlayan bir sıralama sunmuştur. Philon için sağlam olan bir koşullu önermenin diğer üç koşullu önerme anlayışından daha "zayıf” olması Philon'un tanımının daha "güçlü” bir tanımda reddedileceği anlamına gelir. Philon'un tanımı koşullu bir önermede ön-bileşenin doğru ard-bileşenin yanlış olması ihtimalinin dışlanması asgari koşulunu ortaya koymuştur.

\footnotetext{
${ }^{8}$ Empiricus'un Philon ile karşılaştırarak Diodoros Kronos için verdiği örnek şöyledir: “... Philon sağlam bir koşullunun doğru bir ön-bileşen ve yanlış bir ard-bileşene sahip olmayan olduğunu söyler. Gündüz ise ve konuşuyorsam "Eğer gündüz ise, konuşuyorum"da olduğu gibi. Diodoros ise "ne doğru bir ön-bileşeni ve yanlış ard-bileşeni olanaklı olmuş ne de doğru bir ön-bileşeni ve yanlış ard-bileşeni olanaklı olabilecek [mete enedekheto mete endekhetai]" olarak tanımlar. Bu görüşe göre de yukarıda bahsedilen koşullu gerçekten gündüz ise ve sessiz kalmışsam doğru ön-bileşen ve yanlış ard-bileşeni olacağından yanlış görünür, oysa ki "Eğer şeylerin atomik elementleri var değilse, o halde atomik elementler vardır" kıyası "Atomik elementler var değildir" yanlış ön-bileşeni ile başlayıp, ona göre, doğru olan "atomik elementler vardır" ifadesi ile bittiği için doğru görünür." Sextus Empiricus, PH, II 110-113 (İngilizcesi: Bury 1976: 223).

${ }_{9}^{9}$ Bkz. Sextus Empiricus, PH, II 110-113 (İngilizcesi: Bury 1976: 223).
} 


\subsection{Modalite}

Philoncu koşullu önermede ön-bileşen doğru iken ard-bileşenin yanlış olması önermeye yanlış değeri veren tek durum olduğu için bu yanlış değerinin nasıl elde edildiğini göstermek önemli hale gelir. Yanlış bir önerme elde etmek için en basit yolun olanaksız bir önerme bulmak olduğu söylenebilir. ${ }^{10}$ Boethius’un (ö. 524) aktardığına göre Philon'da olanaksız "hiçbir zaman doğruluğu kabul etmeyen" olarak tarif edilir (Boethius, De Int. 234). ${ }^{11}$ Yukarıda Philon'un örneği olarak verilen ve doğruluk değeri yanlış olan koşullu önerme üzerinden olanaksızlık konusuna bakabiliriz. Gündüz ise ve konuşmuyorsam "Eğer gündüz ise, konuşuyorum" önermesinde ard-bileşen, önerme olarak kendi başına olanaksız olmadığı gibi koşullunun ifade ettiği şekliyle gündüz ise konuşuyor olmak da olanaksız değildir. Ancak konuşmuyor isek konuşuyor olmamız olanaksızdır. Şu halde koşullu önermenin ard-bileşeni varsayılan bilgiler çerçevesinde olanaksız olduğu için yanlıştır.

Ard-bileşeni yanlış olan koşullu bir önermenin yanlış olması için ön-bileşeninin de doğru olması gerekir ve Philon'daki yanlış koşullu önerme için varsayılan bilgiler çerçevesinde ön-bileşen de doğrudur. Modalite açısından olanaksız olan önermelerin yanlış değer alması gibi, doğru değeri alan bir modalite de vardır: zorunluluk. Yanlış bir koşullu önermedeki ön-bileşeninin zorunlu bir önerme olduğu öne sürülebilir. Boethius Philon'un zorunluyu "doğru olan ve kendinde olduğu sürece yanlış kabul etmeyen" olarak tanımladığını söylemektedir (Boethius, De Int. 234). ${ }^{12}$ Philon'un yanlış koşullu önerme örneğinde de ön-bileșen gündüz vakti söylenen "Eğer gündüz ise" cümlesidir. Eğer gündüz ise gündüz olmasının zorunlu olduğu söylenebilir. Fakat "Gündüzdür" ifadesi kendi başına zorunlu bir önerme değildir.

Peki bir önermeyi zorunluluk dışında doğru yapan bir modalite var mıdır? Buna olumlu bir yanıt verilebilir çünkü olanaklılık modalitesindeki önermeler de doğru

\footnotetext{
${ }^{10}$ Gauss modern dönemde maddi içerme olarak referansta bulunulan ama bizim Philoncu koşullu önerme diyebileceğimiz konuyu incelerken doğruluğun maddi içermede olanaksızlık açısından tanımlandığını savunmuştur. Ona göre olanaksızın değillenmesi ile de doğruluğun anlamına ulaşırız. Bkz. Gauss 1943: 101.

${ }^{11}$ İnilizcesi, Smith 2014 s. 141.

${ }^{12}$ İngilizcesi, Smith 2014: 141.
} 
doğruluk değeri alabilmektedir. ${ }^{13}$ Boethius Philon'un olanağı, "beyanın kendi içsel doğasıyla doğruluğu kabul etmesi” olarak gördüğünü aktarır. Boethius’a göre Philon, olumsal ile olanaklıyı da aynı görmektedir. Philon’un gerçekleşen şey için de olanaklı tabirini kullanması bunu destekler (Boethius, De Int. 234). ${ }^{14}$ Philon'un yanlış koşullu önermesinde ön-bileşen olan "Eğer gündüz ise" ifadesi yahut doğrudan "Gündüzdür" önermesi olgusal durumun doğruluğuna ihtiyaç duymadan olanaklıdır. Olgusal durum gündüz olduğunu gösteriyorsa olanaklı önerme doğru değeri alır. Olanaklı bir önerme olgusal verilerle çatıştığında yanlış değer almaya da müsaittir.

Andrea Borghini Philon'un olanaklılık anlayışı açıklanırken kullanılan "kendi içsel doğasıyla" ifadesinin "bir önermeyi olanaklı olmamaya sadece kendiyle-çelişme öğesinin dönüştüreceğini” gösterdiğini ve bu durumun mantıksal olanak kavramı olarak yorumlanabileceğini söyler (Borghini 2016: 33). Philon’un koşullu önerme örneklerinden yalnızca birinde yani "Eğer dünya uçuyor ise dünyanın kanatları vardır" koşullu önermesinde “Dünya uçuyor”, "Dünyanın kanatları vardır” önermelerinin kendi başına olanaksız önermeler olduğu söylenebilir. Fakat burada önermelerin kendi içinde mantıksal bir olanaksızlıktan mı yoksa olgusal durum olarak kabul edilen dünyanın fiziksel özellikleri nedeniyle ortaya çıkmış bir olanaksızlıktan mı bahsedildiği açık değildir. Eğer dünya uçuyor olsaydı kanatlarının olması da mantıksal olarak olanaksız görünmez. Bu önermelerde çelişme olup olmadığına karar vermek de kolay değildir.

Yine de olanaksızlık durumuna benzer şekilde bir önermede çelişme olduğu zaman da bu önermenin yanlış olacağı söylenebilir. Aristoteles'in çelişik ifadelerle ilgili yazdıkları bu anlamda yol göstericidir. Aristoteles'e göre beyanda bir çelişme durumu için önermelerde bir doğru ve bir yanlışa: bir evetleme ve bir değillemeye ihtiyaç duyulur (Aristoteles, Yorum Üzerine, 17 a 30) Gündüz vakti iken ve konuşmadığımda söylenmiş olan "Eğer gece ise, konuşuyorum" koşullu önermesinde konuşmuyor

\footnotetext{
${ }^{13}$ Megara okulundan Diodoros Kronos'a atfedilen Master Argümanı'nın Epictetus tarafından aktarılmış formundaki öncüllerinden biri olan "olanaklıdan olanaksız çıkmaz" ifadesi düşünülünce, olanaksız bir önermenin doğruluk değeri yanlış olduğu için doğrudan yanlış çıkma ihtimali yahut doğruyu yanlışın takip etme ihtimalinin olanaklı modalitesine sahip bir önermenin doğruluk değeri alması ile ilgili olduğu da söylenebilir. Bkz. Epictetus Discourses, II, 19, 1-2 (İngilizcesi, Oldfather 1956: 359).

${ }^{14}$ İngilizcesi, Smith 2014: 141.
} 
oluşum konuşuyor olmamla çeliştiği için koşullunun ard-bileşeni yanlıştır. Gündüz vakti söylenmiş olan "Eğer gündüz ise, gecedir” koşullu önermesinde gece ve gündüz olma birbirinin çelişik anlamda olumsuzu olmasa bile karşıt kavramlardır. Philon’un örneklerinde karşıtların bir koşulluda ön-bileşen ve ard-bileşen olarak birlikte kullanılmaları koşullu önermenin doğruluk değerini yanlış hale getirmek için yeterli değildir. Gündüz vakti söylenmiş olan "Eğer gece ise, gündüzdür" önermesi yanlışla başlayıp doğru ile bittiği için doğrudur. Diğer yandan bu önermenin ön-bileşen ve ardbileşeninin yer değiştirdiği ve gündüz vakti söylenen "Eğer gündüz ise, gecedir” koşullu önermesi ise doğru ile başlayıp yanlış ile bittiğinden yanlıştır. Yine de buradaki yanlışlığın nedeni karşıt önermelerin doğruluk değerine olan etkisidir. Bu konuda da Aristoteles yol göstericidir çünkü o çelişmezlik ilkesine dayanan üçüncü şıkkın imkansızlığı ilkesini karşıtlık ve zıtlık kavramları ile açılamıştır: “.. karşıt önermelerin aynı anda doğru olmadıkları..."; "Zıtlar da aynı özneye aynı anda ait olamaz" (Aristoteles, Metafizik, 1011 b 14; 1011b 16-23). Koşullu bir önermeyi bir bütün halinde yanlış yapan şey doğruluğu yanlışlığın takip etmesi olsa da gece ve gündüzün yanlış ve doğru değerleri almasının nedeni bu ikisinin aralarında üçüncü bir doğruluk değeri olmayan karşıt kavramlar olmasıdır.

Philon'un koşullu önermelerindeki ne ayrı ayrı ön-bileşen ve ard-bileşen ne de koşullunun kendisi zorunlu bir doğruluk değeri almasa da ön-bileşen ve ard-bileşen arasındaki doğruluk değeri bağıntısının zorunlu bir ilişkisi olduğu söylenebilir. Koşulludaki ön-bileşen ve ard-bileşen olumsal olarak doğru olabilir ama ikisi de doğru ise koşullu zorunlu olarak doğrudur. Bu zorunluluğun mantıksal bir zorunluluk olduğu söylenebilir. Mantıksal zorunluluk ise nedensellikten farklıdır. Philon'un koşullu önerme örneklerinin arasında her durumda bir nedensellik yoktur. Bu hal sıradan insan mantığına tuhaf gözükmektedir.

\section{Modern Mantık}

Koşullu önermelerin doğruluğunu asgari bir koşulla ön-bileşen doğru iken ardbileşenin yanlış olmaması şeklinde kabul edersek, Megara ve Stoa okulları sonrasında 
Frege'ye kadar bu konunun felsefe tarihi gündeminde pek yer etmeği söylenebilir. 19. yüzyılın ilk çeyreğinde felsefe tarihi kitaplarında Megara okulunun koşullu önerme anlayışının antik kaynaklara başvurularak aktarıldığını görürüz (Krug 1827: 180). Ancak bu aktarımlarda koşullu önermelerin önermeler mantığına bağlı bir doğruluk değerine sahip olduğu anlaşılmamıştır. ${ }^{15}$ Sembolik mantığın ilerleyen on yıllardaki gelişimi ile Megaralı Philon’un koşullu önerme anlayışının önermeler mantığı ile ilgili olduğu fark edilmiştir.

\subsection{Frege}

Frege'nin çalışmalarını yaptığı sıralarda dönemin Almanyası'nda yayınlanan mantık tarihini işleyen eserlerinden haberdar olması mümkünse de 1879'da Begriffsschrift' in yazılma biçimi felsefe tarihine başvurur tarzda olmadığı için Megaralı Philon'un koşullu önerme fikrine dair bir bahse burada rastlanmaz. ${ }^{16}$ Frege'nin bu eserinde koşulluluk temel eklemlerden birisidir. Eserde yargı verilebilir içerikleri temsil eden B [ön-bileşen] ve A [ard-bileşen] işaretlerinin koşul çizgisi ile verildiği grafik ilişkisinde dört olanaktan bahsedilir ve B'nin içeriğinin evetlenip A'nın içeriğinin değillendiği olanak dışlanır. ${ }^{17}$ Frege yargılara doğruluk veya yanlışlık atfedildiğinde

${ }^{15}$ Carl Prantl 1855 tarihli eserinin Megaralılar bölümünde Diodoros Kronos'un koşulluluk anlayışını olanaklılık anlayışına bağlayarak açıklamış ama Philon'a yer vermemiş ancak Stoacıların koşullu yargılarını [hypothetische Urtheil] incelerken Philon'un koşullu önerme anlayışına değinmiştir. Bkz. Prantl 1855: 40, 456. Prantl'ın bu tavrı kendisinin de kaynak olarak kullandığ 1 Ritter'in makalesinden etkilenmiş görünmektedir. Bkz. Ritter 1828: 328-329. Yine 1859 yılında Eduard Zeller, kitabında Megaralı filozofları işlediği bölümde bu filozofların koşullu önerme anlayışı ile ilgili kısa bir özet vermiş fakat konunun mantıksal kuralları açıklamakla ilgili formel doğruluk olduğunu düşünmüştür. Bkz. Zeller 1859: 193.

${ }^{16}$ Bobzien "Frege plagiarized the Stoics" isimli çalışmasında Prantl'ın 1855 tarihli Geschichte der Logik im Abendland kitabı ile Frege'nin yayınlanmış eserlerini ve yazılarını karşılaş̧ırarak Frege'nin bu çalışmadan etkilenmiş olabileceğini hatta yer yer bu etkilenmenin "intihal" denebilecek kadar belirgin olduğunu tartışmışıır. Bobzien Begriffsschrift'teki koşullu önerme açıklamasını, Prantl'ın kitabında "Stoacılar" bölümünde incelenen Philon'a atfedilmiş olan koşullu önermelerin doğruluk değeri incelemesi ile de karşılaştırmıştır. Bkz. Bobzien 2021: 191. 17

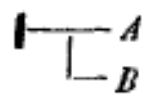

Begrifsschrift'de yukarıdaki işaret "Eğer B ise, o halde A'dır" koşullu önermesinde B'nin doğru A'nın yanlış olduğu olanağın değillendiği, yani bir anlamıyla yanlış doğruluk değeri aldığı, diğer üç olanağın ise 
koşullu önermeye bir bütün olarak doğruluk veya yanlışlık yükler. Bir koşullunun önbileşen yargılanabiliri evetlenmiş, ard-bileşen yargılanabiliri değillenmiş olduğunda koşullu yanlış, diğer 3 halde ise doğrudur. Frege bu durumu A evetlendiğinde B'nin, B değillendiğinde ise A’nın içeriğinin önemsiz olacağı şeklinde de açıklar (Frege, Begriffsschrift, 5-6). Yani ard-bileşenin doğru olması ya da ön-bileşenin yanlış olması bir koşullu önermenin doğruluğu için yeter bir şarttır. Fakat A yanlış ise koşullunun doğruluğu maddi olarak B'nin doğruluk değerine bağlıdır. Zaten Philon'da da mevcut olan bu doğruluk değeri durumlarını Frege'de bir kural halinde buluruz. Ancak yapısal olarak Frege'nin sembolleştirmesi Philon'daki gibi olgusal durumlarla ilgili ek bilgi vermez. A gibi bir işaretin önermesel karşılığı olarak doğruluğu veya yanlışlığı kabul edilip bu değerler üzerinden çıkarımda bulunulur.

Frege'nin Begriffsschrif'teki modalite ilgili görüşlerini yargı türlerinin incelendiği kısımdaki iki paragrafa bulabiliriz. İlkinde zorunluluk apodiktik kavramı eşliğinde açıklanır. Fakat Frege zorunlu bir önermede zorunluluk "yargının kavramsal içeriğini etkilemediğì" için apodiktik yargıların formunun çalışması için önemsiz olduğunu söyler (Frege, Begriffsschrift, 4-5). Devam eden paragrafta olanaklılık ise iki şekilde açıklanır. İlk durumda olanaklılık önermenin olumsuzunun takip edeceği bir yasa olmadığı için önermeyi askıya alma şeklinde sunulur. Örneğin "Dünyanın gelecekte başka bir uzay cismi ile çarpışması olanaklıdır” önermesinde dünyanın gelecekte başka bir uzay cismi ile çarpışmamasını sağlayacak bir yasa bilinmediği için bu çarpışma olanaklı olarak anlaşılır. İkinci durumda ise olanaklılık bir önermenin olumsuzunun genelleştirilmesinin yanlış olması şeklinde sunulur. Bu durum tikel evetleyici yargı olarak düşünülür. Frege örnek olarak "Soğuk algınlığı ölüme neden olabilir” cümlesini verir (Frege, Begriffsschrift, 5). Frege'nin burada kastettiği “Hiçbir soğuk algınlığı

evetlendiği durumun simgesi olarak kullanılmıştır. Frege koşulluluk işaretinin "ve" ve "olumsuzlama" işaretleri kullanılarak da temsil edilebileceğini ifade etmektedir. (Günümüzdeki $\sim(p \wedge \sim q$ ) sembolleştirmesine denk geldiği söylenebilir). Fakat o, koşulluluk işaretini temel almasının çıkarımları daha kolay ifade edebilmek için olduğunu söyler. Bkz. Frege, Begriffsschrift, 20. Bobzien bir önceki dipnotta belirtilen eserinde Cicero'nun koşullu önermeleri olumsuzlama ve "tümel evetleme" yoluyla yorumladığı satırlara işaret ederek Prantl'da bu satırlar alıntılanmasa bile Frege'nin olası bir Prantl etkisi ile Cicero'nun kitabınının mantıkla ilgili kısımlarını kendisinin okumuş olabileceğini belirtir. Bkz. Bobzien 2021: 193. 
ölüme neden olmaz” önermesinin yanlış olmasıdır. Frege eserin ilerleyen sayfalarında "Hiçbir M bir P değildir” önermesinin değillenmesinin "Bazı M'ler P'dir” i doğurduğunu açıklamaktadır. $\mathrm{Bu}$ da bir M'nin P olmasının olanaklı hale gelmesi demektir (Frege, Begriffsschrift, 24). ${ }^{18}$ Şu halde "Hiçbir soğuk algınlığı ölüme neden olmaz” önermesinin değillenmesini “Soğuk algınlığının ölüme neden olması olanaklıdır" şeklinde gösterebiliriz. Reinhardt Grossmann, Frege'nin ifadelerinin aktüel hale gelmiş bir olgu hiçbir kanunla çelişmediği için olanaklı olarak gerçekleşmiş anlamında anlaşıldığını söyler (Grossmann 2006: 31).

Philon'da görmüş olduğumuz koşullu bir önermenin ön-bileşeni ve ard-bileşeni arasında nedensel bir bağlantı şartının olmaması Frege'de daha açık hale gelmiştir. Frege'ye göre günlük dilde "eğer” ile başlayan bir koşullu cümle ne kadar nedenselliği gösterir gibi anlaşılsa da cümleyi oluşturan içerikler arasında nedensel bir bağlantı şartı bulunmamaktadır. Örneğin "Eğer güneş parlıyor ise, 3x7=21" doğru koşullu önermesinde nedensel bir ilişki yoktur. ${ }^{19}$ Nedensel bağlantıların genelde fiziksel alanda olduğunu kabul ettiğimizde Frege'nin de dahil olduğu 19. yüzyıl mantığında sembolleştirme çabalarında fiziksel alanla sınırlanmama kaygısının ön plana çıktığı düşünülebilir. Joan Weiner'e göre Frege Begriffsschrift'te konu içeriğinden etkilenmeyen yani sadece nedensellikle bağlanmış olmayan bir koşullu önerme sembolü bulmak istemiştir (Weiner 2004: 32). Frege açısından nedensellik genellik olduğu zaman bahsedilebilir bir şeydir (Frege, Begriffsschrift, 6). "Ĕger bir şeyin X özelliği varsa P özelliği de vardır” ifadesini “Tüm X'ler P'dir” diye ele almak Frege için bir nedensellik bağlantısından bahsetmek anlamına gelir. ${ }^{20}$ Onun genellik anlayışı Aristotelesçi bir tümelliğe benzemektedir. Frege'nin olanaklılığ ve nedenselliği açıkladığı paragraflardaki bilgiler göz önüne alında "Hiçbir soğuk algınlığı ölüme neden olmaz" ve "Soğuk algınlığı ölüme neden olabilir" önermeleri arasındaki ilişki

\footnotetext{
${ }^{18}$ İngilizcesi: van Heijenoort 1967: 28.

${ }^{19}$ Prantl'ın Philoncu koşullu önerme anlayışındaki nedensellik sorunundan bahsetmesi ve Frege'nin buna Bobzien'in incelediği Compund Thoughts (Almacası: Gedankengefüge 1923) eserinden önce Begriffsschrift'de cevap vermesi Bobzien'in 23. dipnotta bahsedilen iddialarını güçlendirir görünmektedir. Bkz. Prantl 1855: 455; Bobzien 2021: 191.

${ }^{20}$ Bkz. Frege, Begrisffschrift, 23 (İngilizcesi: van Heijenoort, 1967: 27).
} 
Aristotelesçi bir olumlu tümel önerme ile onun olumsuzu olan tikel önerme arasındaki çelişki ilişkisine benzemektedir. Frege zaten bu tür yargılar için nedenselliği açıkladığı bölümün sonunda mantıksal karşıtlık karesini de göstermiştir (Frege, Begriffsschrift, 24). ${ }^{21} \mathrm{Bu}$ durumda eğer tikel önermenin olanaklıyı gösterdiği düşünülürse onun çelişiğinin de olanaksızı gösterdiği yorumu yapılabilir mi? Frege modal kavramların yargı içeriklerine etki etmesini reddettiği için bu soruya cevap vermek zordur. Yine de Frege'nin olanaklılık söz konusu olduğunda Philon'daki gibi olgusal durumlara başvurduğu söylenebilir.

\subsection{Peirce}

Peirce modern mantıktaki koşullu önermelerin sembolleştirilmesi ve anlaşılmasına en çok etki eden filozoflardandır. O, 1884 yılında kaleme aldığı Mantığın Cebri Üstüne yazısında "Eğer a ise, b'dir" ("If it is a, it is b") koşullu önermesini ifade etmek için Frege gibi bağımsız bir işaret geliştirmiştir. Bu işaret günümüzde modern mantıktaki "ise" sembolüne benzemektedir:

$$
\mathrm{a}-<\mathrm{b}^{22}
$$

Peirce bu sembole ilişkilenen formülün "kopulanın cebiri” olarak isimlendirdiği şey olduğunu söyler. Ona göre " $a-<$ b önermesi ya a yanlış ya da b doğru ise doğru olarak anlaşılır". Önermenin yanlış olduğu tek durum "eğer a doğru ise b'nin yanlış olması" ile ortaya çıkar. Peirce bu eserde bireylerin doğruluğundan bahsederek v'nin doğruyu, f'nin ise yanlışı işaret ettiğini söyler. Yani a'ya ne dersek diyelim $\mathrm{f}-<\mathrm{a}$ ve a — < doğru olacaktır. Buna ek olarak a doğru veya yanlış değerlerinden birini aldığı zaman ya $\mathrm{v} —<$ a ya da $\mathrm{a} —<$ f önermelerinden biri doğru olacaktır (Peirce 1993: 112).

\footnotetext{
${ }^{21}$ Frege koşul çizgisini açıkladığı yerde üç “olanak”tan bahsedip üçüncü olanağın gerçekleşmediğini söylemektedir. O yine aynı yerde doğru ve yanlış tabirleri yerine değilleme ve evetleme tabirini kullanmaktadır. Bu durumda olanağın gerçekleşmemesinin bir anlamda o olanağın değillenmesi halinde "olanaksızlık" ve yanlış ile sonuçlanması olarak yorumlanıp yorumlanamayacağı sorusu doğar. Bkz. Frege, Begriffsschrift, 5 .

${ }^{22}$ Günümüzdeki sembol: $\mathrm{p} \rightarrow \mathrm{q}$
} 
Peirce'nin en geç 1896 yılında Megaralı Philon'dan haberdar olduğunu söyleyebiliriz. Ancak o, Philon’un koşullu önerme anlayışını değerlendirirken tarihi kaynaklara bağlı kalmayı önemsemiş gözükmemektedir. Peirce Philon’un örneklerini kullanmak yerine kendisi benzer örnekler oluşturmuş ve bu örneklerin Philon tarafından nasıl işlendiğini değil Philoncularca nasıl anlaşılacağını ele almıştır. Mesela "Şimdi şimşek çakıyorsa, gök gürleyecek" önermesi Peirce'e göre Philoncular tarafindan "Şimşek çakmıyor ya da gök gürleyecek"23 diye anlaşılır ve doğru doğruluk değeri alır. Aynı önerme "Şimşek çakıyor ve gök gürlemeyecekse" yanlış olur. Peirce felsefe hayatının farklı dönemlerinde koşullu önermelerin doğruluk değeri açısından bir Philoncu olduğunu ilan etmiştir (Peirce 1976: 169).

\subsubsection{Modalite}

Peirce olanaklılık ve koşullu önerme ilişkisine farklı bir bakış açısı getirmiştir. Peirce'e göre olanağın alanı bir durumda dar, bir başka durumda ise daha geniş incelenmeye müsaittir. $\mathrm{O}$, olanağı ilk aşamada mevcut şeylerin aktüel durumu ile sınırlar. Bu nedenle " $\mathrm{a} — \mathrm{~b}$ önermesi eğer a yanlışsa veya eğer $\mathrm{b}$ doğru ise doğru, fakat eğer b yanlış iken a doğru ise yanlıştır”. Kendimizi bu şekilde aktüel durumla sınırlasak da mantıksal zorunluluk ile doğru olan bir formül bulduğumuzda, formülümüz sadece şeylerin aktüel durumuna sınırlanmayarak mantıksal olanağın alanı içindeki herhangi bir tekil duruma genişler (Peirce 1885: 187). Peirce bununla ne kastettiğini yaklaşık on yıl kadar sonra daha açık hale getirir. O, olanaklıyı en geniş anlamıyla şöyle görür: "her halükarda belirli bir bilgi durumu altında yanlış olduğu bilinmeyen". Özsel olanak olarak nitelenebilecek bu olanağın "mantık kuralları dışında bir şeye ihtiyacı bulunmaz". Özsel olanak dışında tözsel [substantive] olanaktan da bahseden Peirce bu ikinci olanağın her şeyi bilmeyi gerektireceğini düşünür. Ona göre Philoncu mantıkçılar koşullu önermeleri çalışmaya başlamak için her şeyi bilme durumunu şart koşmaktadır. Yani her şeyi bilene yanlış olarak bilinmeyen şey olanaklı

\footnotetext{
${ }^{23}$ Günümüzdeki sembolleştirme ile ( $\sim p$ V q)
} 
olacaktır (Peirce 1896: 33). ${ }^{24}$ Diğer bir deyişle “olanaklı yalnızca doğru olandır” (Peirce 1976: 277).

Peirce'e göre "Ĕğer bir şey, A, doğru ise, o halde diğer şey, B, doğrudur" formundaki koşullu önerme Philon'u takip eden mantıkçılarca herhangi bir olanaklı çerçeve altında şu anlamda alındı: "A doğrudur (böyle bir çerçeve vardır diye iddia etmeden), bahsedilen çerçevede B doğrudur”. Bu nedenle Philoncular için "A'nın doğru olacağı olanaklı bir çerçeve yoksa koşullu önerme bir iddiada bulunmaz" ve olgularla çatışmayacağı için B ne olursa olsun doğru olur. Peirce'e göre mantıkta iki şeyi birden iddia etmek uygun olmadığı için mantıkçılar koşullu önerme konusunda Philon'a yakındır. Peirce bu koşullu önerme anlayışının sağduyuya elverişsiz sonuçları olduğunu kabul eder. Ona göre "normal konuşmada koşullu bir önermenin ön-bileşenini olanaksız bir önerme varsayımı ile kurmayız". Bu ön-bileşenin bir çeşit "olanağın kastedildiği olanaklı durumlardan birinde doğru olacağını” düşünürüz (Peirce 1976: 276).

Olanaksız olduğu için yanlış olan bir ön-bileşenin herhangi bir ard-bileşen ile doğru sonuç doğurmasının sağduyuya değilse de mantığa hitap eden yanı ve dilde de kullanım alanı vardır. Örneğin "Eğer annemin annesi dişi değil ise, o halde dayım dişidir” koşullu önermesini düşünelim. Dayımın dişi olması ne kadar mümkünse, annemin annesinin dişi olmaması da o kadar mümkündür. Mantığımız böyle bir durumda yanlış bileşenleri olan bir koşullu önermeyi bir bütün olarak tuhaf bulmamaktadir.

\subsection{Russell}

\subsubsection{Maddi İçerme ve Formel İçerme}

Russell'ın eserlerini yazdığı dönemde koşullu önermelerle ilgili hem Frege'nin hem de Peirce'in kendisinden önce ortaya koymuş olduğu çalışmaları takip ettiği tahmin

\footnotetext{
${ }^{24}$ Peirce aynı yerde bu durumu şu şekilde de açıklar "Fakat sıradan Philoncu koşullu "Şeylerin herhangi bir olanaklı durumunda, i (i şeylerin aktüel durumuna gönderimde bulunur), ya A[i] doğru değildir, ya da $\mathrm{B}[\mathrm{i}]$ doğrudur".
} 
edilebilir. O, 1903 tarihli “önermeler kalkülüsünü” incelediği Matematiğin İlkeleri eserinin önsözünde Frege'nin çalışmalarının kendisininkini öngördüğünü belirtirken, “ilişkiler kalkülüsünün” Peirce tarafından geliştirildiğini de teslim eder (Russell 1903: 23). Russell bu eserde önermeler kalkülüsünün her önermesinin hipotez ve "ardbileşen" olarak maddi içerme iddiası olduğunu söyleyerek maddi içermeyi formel içermeden ayırmıştır. Maddi içerme bir bütün olarak önermeler arası ilişkide geçerlidir. Formel içerme ise önermesel fonksiyonlar arasında değişkenin tüm değerleri için biri diğerini içerdiğinde gerçekleşir. Russell maddi içerme ve formel içerme arasındaki farkı Eukleides'ten bir örnekle açıklar. Eukleides'in Elementler kitabındaki beşinci önerme (postula), dördüncü önermeden çıkmaktadır. Eğer dördüncü önerme doğru ise beşinci de doğrudur fakat beşinci yanlış ise dördüncü de yanlıştır. Bu durum Russell'a göre maddi içerme durumudur çünkü her iki önerme de mutlak değişmezdir, anlamları için bir değişkene değer vermeye bağımlı değillerdir. Diğer yanda her iki önermenin kendisi ise formel içermeyi gösterir (Russell 1903: 13). Russell'ın maddi içermeyi Eukleides örneği ile açıklarkenki ifadeleri modus ponens ve modus tollensi hatırlatmaktadır. Eukleides'in dördüncü önermesini koşullunun ön-bileşeni (p), beşinci önermesini de ard-bileşeni (q) olarak düşündüğümüzde şu çıkarımları elde ederiz;
Eğer $p$ ise $q$
Eğer $\mathrm{p}$ ise $\mathrm{q}$
$\mathrm{p}$
Değil-q
O halde $\mathrm{q}$
O halde değil-p

Bahsedilen dördüncü ve beşinci önerme arasındaki maddi içerme ilişsisi iki önerme de değişkene sahip olmayan ve doğruluk değeri alabilen şeklinde değerlendirilir. Fakat bu önermeleri kendi başlarına tek tek formel içerme ilişkisi açısından ele aldığımızda maddi içermenin değişmezlerden oluşan önermesinden farklı olarak bu tek tek önerme fonksiyonlarının doğruluk değeri alabilmesi için değişkenlerine bir değer atamamız gerekir. Ayrıca formel içermede değişkenin "tüm değerleri için" ifadesi de Russell tarafından belirtildiği için bu içermede tümel niceleme 
özelliğinden de bahsedilebilir. ${ }^{25}$ Russell maddi içermenin formel içermeden farkının daha iyi anlaşılabilmesi için bir örnek daha verir. "Sokrates bir insandır, o halde Sokrates bir ölümlüdür" ifadesinde Sokrates sanki bir değişkenmiş gibi, Sokrates yerine başka bir insan da bu denkleme konulabilirmiş gibi hissedilmektedir. Russell'a göre burada cümleyi "o halde" ifadesiyle değil de "Sokratesin bir insan olması Sokrates'in ölümlü olmasını içerir (imply)" cümlesi ile kurarsak "Sokrates'in yerine sadece başka bir insan değil başka herhangi bir entite de ikame edebiliriz”. Burada değişkenlerden oluşan değil değişmezden oluşan bir önerme ilişkisi olduğu için maddi içerme vardır ama kastedilen de formel içermedir (Russell 1903: 13-14).

Sembolleştirme açısından baktığımızda Russell maddi içermeyi bu eserde "p içerir q" tabiri olarak düşünmektedir. ${ }^{26}$ Ona göre eğer "p içerir q" ise, "o halde p ve q'nun her ikisi de doğru veya her ikisi de yanlış, yahut p yanlış q doğrudur”. Burada p, q'yu içeriyorsa “q’nun yanlış p'nin doğru olması olanaksız”, “q'nun doğru veya p'nin yanlış olması zorunludur” (Russell 1903: 15). Maddi içerme Russell'e göre geçerli bir çıkarımı mümkün kılacak bir ilişki biçimidir. Bu ilişki biçimini "p doğru ise q da doğru olmalıdır" tarzında açıklamak, "eğer ise" ve "o halde" zaten bir içermeyi (implication) gösterdiğinden bizi döngüsel bir tanımla karşı karşıya bırakır. Russell söz konusu önermelerin doğruluk değerlerine başvurmadan da maddi içermenin geçerli halde olduğunu belirtmektedir (Russell 1903: 33).

Russell'ın 1910 yılında Whitehead ile birlikte yazıdğı Principia Mathematica eserinde ise "içermesel fonksiyonu (implicative function)" "p ve q argümanlarına sahip önerme fonksiyonu olarak ve değil-p veya q doğrudur, yani “ p v q” önermesi” olarak gösterilmiştir. ${ }^{27}$ "Böylece p doğru ise $\sim$ p yanlıştır ve “ p v q" önermesiyle kalan tek alternatif q'nun doğru olmasıdır”. P ve “ p v q”"nun her ikisinin de doğru olması

\footnotetext{
${ }^{25}$ Bkz. Russell 1903: 12.

${ }^{26}$ Russell 1903: 16 not. Russell için q doğru veya p yanlış iddiası “p içerir q" iddiasına eş değerdir. Fakat "eşdeğerlik karşılıklı içerme gerektirdiği için" içerme temel olarak kalır ve "tikel evetleme ile tanımlanamaz". Tikel evetleme ise içerme ile tanımlanabilir. Doğruluk ve yanlışlık bize içermeyi tanımlama gücü vermemektedir. Bkz. Russell 1903: 14-15.

27 Principia Mathematica eserinin sisteminde olumsuzlama ve tikel evetleme temel eklemlerdir. Bkz. Whitehead \& Russell 2002: 6.
} 
halinde, $\mathrm{q}$ da doğru olacaktır. Bu anlamda “ p v q" önermesi “p içerir q" olarak yorumlanır. Fakat buradaki "içerir” kullanımı "p ve q arasında bir bağdan başka bir şey değildir" ve "değil-p veya q" ile de ifade edilebilir. "P içerir q" için yani “ p v q" için de kullanılan sembol eserde "p $\supset$ q" olarak verilir. Bu sembol "Eğer p ise, o halde q" diye de okunabilir. İçermede bir değişken bulunduğu durumda bu "formel içerme" olacaktır. Russell ve Whitehead ilk içermeyi formel içermeden ayırmak için "maddi içerme" tabirini kullanmayı seçtiklerini belirtirler (Whitehead \& Russell 2002: 7). Aynı eserde formel içerme yüklem mantığı ve değişkenler ile açıklanır. "Tüm insanlar ölümlüdür” önermesi “"x insandır' içerir 'x ölümlüdür' x'nin tüm olanaklı değerleri ile” ifadesine eşdeğerdir. Burada x'in insan olan değerle sınırlanmayıp, “ 'x bir insandır' içerir 'x ölümlüdür"' ile herhangi bir değeri alması yani doğru veya yanlış değeri alması formel içerme olarak anlaşılır (Whitehead \& Russell 2002: 45).

Russell 1905 yılında "Zorunluluk ve Olanaklılık" başlığıyla sunduğu ve ölümünden sonra yayınlanan yazısında zorunluluğun ve olanaklılığın tek bir temel kavramı olmadığına karar vererek modalite konusunu Frege gibi mantığın dışında bırakır. Çünkü ona göre önermeler doğru ya da yanlıştır ve doğruluk açısından olumsallık ve zorunluluk kavramlarını ayırt etmenin buna etkisi olmayacaktır (Russell 1994: 520). ${ }^{28}$ Yine de Russell aynı yerde zorunlu önermelerin doğru olduğu kabulüne karşı çıkmaz ve çelişiği zorunlu olmayan önermenin olanaklı olduğunu kabul eder (Russell 1994: 508). Bu ifade çelişiği zorunlu olan önermenin olanaksız bir önerme olduğunu işaret eder ve buradan olanaksız bir önermenin yanlış doğruluk değeri alacağ çıkarılabilir.

Russell'ın 1903 yılındaki maddi içerme açıklamasını yaparken modus ponens ve modus tollensi kullanmasını göz önüne alarak bu iki çıkarım kuralını birleştirip

\footnotetext{
${ }^{28}$ Lewis ve Langford'un A Survey of Symbolic Logic'te maddi içermeye karşı çıkmasının diğer bir nedeni bu durumdur. Çünkü bir önermenin doğru olması ile mantıksal zorunlu olmasını ve yanlış olması ile mantıksal olanaksız olmasını ayırmamak sorunludur. Bkz. Lewis \&Langford: 1959: 143,160. Stephen F. Barker'e göre Principia sisteminde sadece zorunlu doğru önermeler değil herhangi bir doğru önerme de her önermece içerileceği için Lewis zorunlulukla doğruluğun birbirine geçtiğini düşünmüştür. Ancak Barker'a göre Lewis, $\supset$ eklemi ile sıkı içermenin aynı gramatik seviyede olduğunu düşünüp maddi içerme sadece doğruluk fonksiyonu ile ilgili bir eklem iken onu bir çıkarım formu gibi ele almıştır. Barker 2006: 14 .
} 
düşündüğümüzde mantıksal zorunluluk açısından modus ponens'te koşullu önermenin ön-bileşenini ifade eden öncül doğru olursa ard-bileşenini gösteren sonuç da doğru; modus tollens'te aynı koşullu önermenin ard-bileşenini ifade eden öncül yanlış olursa ön-bileşenini gösteren sonuç da yanlış olmak zorundadır. Maddi içermede doğru önbileşen ve yanlış ard-bileşenli koşullu önermelerin yanlış olmasının nedenlerinden birinin bu mantıksal zorunluluk olduğu söylenebilir. Peki, ön-bileşeni ne olanaksız ne de zorunlu olan bir koşullu önerme için ne söylenebilir? Modus ponens ve modus tollens açısından aynı koşullu önermenin ön-bileșenini ifade eden öncül yanlış olduğunda çıkarımın değeri belirsiz olacaktır. Bu durum mantıksal olanak için bir aralık bırakılması olarak görülebilir. Russell açısından maddi içermedeki mantıksal olanağın bir koşullu önermenin doğruluğu için asgari şartı sağlayacağı söylenebilir. Philoncu bir koşullu önerme açısından ise bu asgari şart ön-bileşen ve ard-bileşenin olanaklı veya olumsal olması ile gerçekleşebilir.

Russell da incelediğimiz diğer filozoflar gibi maddi içermenin nedensellik ile ilgili olmamasına bir açıklama getirmiştir. Normal şartlarda “ "Sokrates bir insandır” önermesinden " $2+2=4$ "” ifadesinin çıkarılabileceği (deduced) veya her ikisinin de “Sokrates bir üçgendir" tarafından içerildiğini”" iddia etmeyiz. Fakat Russell bu iddiaya karş1 isteksizliğin maddi içerme gereken yerlerde formel içermeyi düşünmemizden kaynaklandığını düşünür. Ona göre maddi içermenin bize tanıdık olmaması onun yanıltıcı olduğunu kanıtlamak için yetersizdir (Russell 1903: 34).

\section{Sonuç}

Koşullu önermelerin doğruluk değeri ile ilgili açıklamayı ilk veren filozoflardan birisi olan Megaralı Philon bu tarz önermelerin doğruluğunu sağlayacak asgari şartı ortaya koymuştur. Philon'un verdiği örneklerde varsayılmış olan olgusal durumlar koşullu önermelerin doğruluğu için bir etkendir. Philon'un olanaksızlık, zorunluluk ve olanakl1lık modaliteleri ile ilgili görüşü koşullu önermelerin doğruluğu ile ilişkili haldedir. Koşullu önermeler modern dönemde Frege'nin sembolik mantığında önemli bir yer kazanmış olsa da varsayılmış olgusal durumlar ve modalite ile ilgili tartışmaya 
onda doğrudan rastlanmaz. Ancak Frege'nin nedenselliği genellik ile bağlaması ve genelliği bir çeşit tümellik halinde ele alarak tikel önermelerin olanaklılığını bu ilişkiden çıkarması onun olgusal durumu modaliteden tamamen dışarıda tutmadığını göstermektedir. Russell hem koşullu önermelerin doğruluk fonksiyonu değeri konusunda hem de mantıkta modalite açısından Frege'yi takip etmiştir. Philon'un koşullu önermelerinin doğruluk değerlerine denk gelen maddi içerme tabirinin felsefede yerleşmesinin nedeni Russell'dır. O, modal kavramları mantıksal analizinde önemsiz görmüş olsa da maddi içerme anlayışının modus ponens ve modus tollens ile ilişkisine dikkat edildiğinde mantıksal olanağın doğruluk için asgari bir koşul olarak ortaya çıktığı fark edilmektedir. Peirce, koşullu önermeler için Frege ile çok yakın tarihlerde Frege'ninkiyle koşut bir doğruluk değeri sunmuş ve modern mantıktaki koşullu önerme anlayışının ve sembolünün birçok unsurunu belirlediği gibi koşullu önermelerin doğruluk değerini mantıksal olanak temelinde açıklamaya çalışmıştır. O, Frege'nin aksine bu konunun tarihsel öncülü olan Philon'a birçok kez atıfta bulunmuş ve Philon'un anlayışını tartışmıştır. Tarihsel gelişim açısından Philon'un koşullu önerme örneklerinde olanak kavramı ilk aşamada Aristotelesçi çelişmezlik ilkesine bağlı bir çelişmeme durumu olarak açıklanabilir görünse de Philon'un modalite teorisinin gösterdiği bir mantıksal zorunluluk ve mantıksal olanak anlayışının modus ponens ve modus tollens çıkarımlarının kuralları ile birleşerek Russell'ın maddi içerme anlayışında daha ileri bir boyuta taşındığı söylenebilir. 


\section{KAYNAKÇA} Yayınları.

ARISTOTELES (1996). Metafizik, çev. Ahmet Arslan, 2.b, İstanbul: Sosyal Kitabevi.

ARISTOTELES (2002). Yorum Üzerine, çev. Saffet Babür, Ankara: İmge

BARKER, Stephen F. (2006). "Lewis on Implication", Transactions of the Charles S. Peirce Society, 42(1)/2006: 10-16.

BOBZIEN, Susanne (2008). "“The Megarics", The Cambridge History of Hellenistic Philosophy, ed. K. Algra, J. Barnes, J. Mansfeld ve M. Schofield, Cambridge UP.

BOBZIEN, Susanne (2021). "Frege Plagiarised the Stoics", Themes in Plato, Aristotle, and Hellenistic Philosophy, ed. Fiona Leigh, School of Advanced Study University of London Press.

BOETİ̈, Anicii Manlii Severini (MDCCCLXXX). Commentarii In Librum Aristotelis ПЕPI EPMHNEIA, , pars posterior, rec. Carolus Meiser, Lipsiae, [İngilizcesi: Boethius (2014). On Aristotle On Interpretation 1-3, çev. Andrew Smith, Bloomsbury].

BORGHINI, Andrea (2016). A Critical Introduction to the Metaphysics of Modality, Bloomsbury.

CICERO, M. T. (1872). Academic Questions, Treatise de Finibus and Tusculan Disputations, tr. C. D. Yonge, London.

(https://www.loebclassics.com/view/marcus_tullius_ciceroacademica/1933/pb_LCL268 .653.xml Latince Çevrimiçi: 25.08.2020

EPICTETUS (1956). The Discourses As Reported By Arrian, The Manual and Fragments, vol. I, çev. W. A. Oldfather, Harvard University Press.

FREGE, Gottlob (1879). Begriffsschrift, Halle, Verlag von Louis Nebert. [İngilizcesi: Jean van Heijenoort, From Frege to Gödel, 1967].

GAUSS, Charles E. "The Interpretation of Implication," Philosophy of Science, 10(2)/1943: 95-103.

GROSSMANN, Reinhardt (2006). Meinong-Arg Philosophers, Routledge.

KNEALE, William \& Martha KNEALE (1971). The Development of Logic, Oxford.

KRUG, Wilhelm Traugott (1827). Geschichte der Philosophie alter Zeit, Leipzig: Gerhard Fleischer. 
LEWIS, C. I. (1912). "Implication and the Algebra of Logic," Mind, 21(84)/1912: 522-531.

LEWIS, C. I. \& C. H. LANGFORD (1959). Symbolic Logic, Dover Publications.

MATES, Benson (1961). Stoic Logic, Berkeley and Los Angeles: University of California Press.

O’TOOLE, Robert R. \&. Raymond E. JENNINGS (2004). "The Megarians and the Stoics", Handbook of the History of Logic - Volume 1: Greek, Indian and Arabic Logic, Elsevier.

PEIRCE, Charles S. (1885). "On the Algebra of Logic: A Contribution to the Philosophy of Notation," American Journal of Mathematics, 7(2)/1885: 180-196.

PEIRCE, Charles S. (1896). “The Regenerated Logic,” The Monist, 7(1)/1896: $19-40$. Publishers.

PEIRCE, Charles S. (1976). The New Elements of Mathematics, Mouton

PEIRCE, Charles S. (1993). Wiritings of C. Peirce, vol. 5, ed. C. J. W. Kloesel, Indiana UP.

PRANTL, Carl (1855). Geschichte der Logik im Abendlande, Leipzig: Verlag von S. Hirzel.

QUINE, Willard Van Orman (1940). Mathematical Logic, New York: Norton.

RITTER, Heinrich (1828). "Bemerkungen über die Philosophie der Megarischen Schule," Rheinisches Museum für Philologie, Geschichte und griechische Philosophie, 2. Jahrg., 3. H., pp. 295-335.

RUSSELL, Bertrand (1903). The Principles of Mathematics, Cambridge UP.

RUSSELL, Bertrand (1994). The Collected Papers of Bertrand Russell, vol. 4, Routledge.

SEXTI Empirici (MCMXII- MCMXIV). Opera I II, B. G. Teubneri.

SEXTUS Empiricus (1976). Outlines of Pyrrhonism, trans. R. G. Bury, Harvard UP.

SEXTUS Empiricus (2005). Against the Logicians, ed. R. Bett, Cambridge UP.

WHITEHEAD, Alfred North \& Bertrand RUSSELL (2002). Principia Mathematica, Camgridge UP.

WEINER, Joan (2004). Frege Explained, Open Cout Publishing.

ZELLER, Eduard (1859). Die Philosophie der Griechen in ihrer geschichtlichen Entwicklung, Tübingen. 